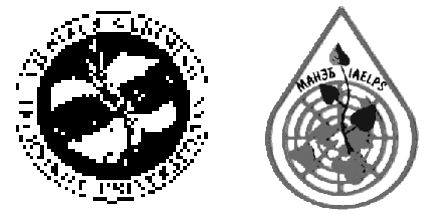

\title{
CHANGES OF NATURAL IONIZING RADIATION IN ANTHROPOGENIC OBJECTS
}

\author{
Viktorija Bogdevičienė, Milda Pečiulienė, Aloyzas Girgždys \\ Laboratory of Nuclear Hydrophysics, Vilnius Gediminas Technical University, \\ Sauletekio al. 11, LT-10223 Vilnius-40, Lithuania. E-mail: algi@fm.vtu.lt
}

Received 6 Jun 2005; accepted 23 Jun 2005

\begin{abstract}
Dosimetric investigations that were performed in various geographic places, mostly connected to anthropogenic activities, are observed in this work. Equivalent dose rate was measured with a radiometer SRP-68, 0,3 m above the point of investigation.

It is determined that equivalent dose rate changes from $97 \mathrm{nSv} / \mathrm{h}$ measured above a non-arable field soil to $219 \mathrm{nSv} / \mathrm{h}$ measured in a tunnel. The hignest values of equivalent dose rate are in closed buildings with a bad ventilation system. It is noticed that the specific activity of ${ }^{40} \mathrm{~K}$ and ${ }^{226} \mathrm{Ra}$ changes depending on the depth of a trench. The specific activity of ${ }^{40} \mathrm{~K}$ is the highest at the deepest point $(441 \mathrm{~Bq} / \mathrm{kg})$ of a trench; the highest specific activity of ${ }^{226} \mathrm{Ra}$ is at the ground level $(37 \mathrm{~Bq} / \mathrm{kg})$.
\end{abstract}

Keywords: ionizing radiation, natural radionuclides, dosimetry, equivalent dose rate, specific activity.

\section{Introduction}

In the last years there has been an increasing interest in artificial and natural radionuclides present in the environment and their possible effects on human health. Radionuclides can be transported at long distances from their source of emission, removed from the atmosphere, deposited in the biosphere and hydrosphere and enter the human population by several pathways [1-2]. The widely spread natural radionuclides are from uranium $\left({ }^{238} \mathrm{U}\right)$, thorium $\left({ }^{232} \mathrm{Th}\right)$, actinium $\left({ }^{235} \mathrm{Ac}\right)$ and potassium $\left({ }^{40} \mathrm{~K}\right)$ [3].

All building materials contain various amounts of natural radioactive nuclides. Materials derived from rock and soil contain mainly natural radionuclides of the uranium and thorium series, and the radioactive isotope of potassium. In the uranium series, the decay chain segment starting from radium is radiologically the most important and, therefore, reference is often made to radium instead of uranium. The worldwide average concentration of radium, thorium and potassium in the Earth's crust is about $40 \mathrm{~Bq} / \mathrm{kg}, 40 \mathrm{~Bq} / \mathrm{kg}$ and $400 \mathrm{~Bq} /$ $\mathrm{kg}$, respectively [4]. Radiation exposure due to building materials can be divided into external and internal exposure. The internal exposure is caused by the inhalation of radon, thoron and their short-lived decay products. Radon is part of the radioactive decay series of uranium which is present in building materials. Because radon is an inert gas, it can move rather freely through porous media, such as building materials, although usually only a fraction of that produced in the material reaches the surface and enters the indoor air. The most important source of indoor radon is the underlying soil.

The purpose of setting controls on the radioactivity of building materials is to limit the radiation exposure due to materials with enhanced or elevated levels of natural radionuclides. The doses to the members of the public should be kept as low as reasonably achievable [5]. It is very important to evaluate natural radionuclide spread in the environment.

In Lithuania and other countries radionuclide specific activity in building materials is different. The specific activity of ${ }^{226} \mathrm{Ra}$ in cement in India $(151 \mathrm{~Bq} / \mathrm{kg})$ is almost four times bigger than that in Lithuania (42 Bq/ $\mathrm{kg})$. The specific activity of ${ }^{226} \mathrm{Ra}$ in cement in Algeria $(41 \mathrm{~Bq} / \mathrm{kg})$ and in Israel $(48 \mathrm{~Bq} / \mathrm{kg})$ is similar to that in Lithuania $(42 \mathrm{~Bq} / \mathrm{kg})$. The measured value of ${ }^{226} \mathrm{Ra}$ in a sample of gravel in Lithuania $(12,2 \mathrm{~Bq} / \mathrm{kg})$ differs not very much from Israel's gravel $(15 \mathrm{~Bq} / \mathrm{kg})$, and in Algeria the specific activity of ${ }^{226} \mathrm{Ra}(24 \mathrm{~Bq} / \mathrm{kg})$ is twice bigger than in Lithuania. The specific activity of ${ }^{226} \mathrm{Ra}$ in bricks made of clay in Algeria and Germany $(65 \mathrm{~Bq} / \mathrm{kg}$ ) is twice bigger than in Lithuania $(32,5 \mathrm{~Bq} / \mathrm{kg})$. The specific activity of ${ }^{40} \mathrm{~K}$ in cement in Israel is almost the same as in Lithuania but three times smaller than in Algeria $(420 \mathrm{~Bq} / \mathrm{kg})$, in Lithuania $-157 \mathrm{~Bq} / \mathrm{kg}$. The spe- 
cific activity of ${ }^{40} \mathrm{~K}$ in gravel in Israel is six times less than in Lithuania, but in Algeria $(260 \mathrm{~Bq} / \mathrm{kg})$ it is similar to that in Lithuania $-300 \mathrm{~Bq} / \mathrm{kg}$. The specific activity of ${ }^{40} \mathrm{~K}$ in clay in Germany and Lithuania is the same $(550 \mathrm{~Bq} / \mathrm{kg})$. The specific activity of ${ }^{40} \mathrm{~K}$ in sand in Lithuania $(238 \mathrm{~Bq} / \mathrm{kg})$ is four times bigger than in Israel, in India, Germany and Algeria the specific activity of ${ }^{40} \mathrm{~K}$ in the sand is three times less $(70 \mathrm{~Bq} / \mathrm{kg})$ than Lithuania [6].

The main goal of the work was to evaluate natural radionuclides in anthropogenic objects ant to compare the results with the natural environment.

\section{Investigation methodology}

There are numbers of methods and variations for the detection and measurement of radioactivity: ionization chamber, Geiger tube, semiconductor detector, scintillation detector, Cerenkov detector. All of them are based on the ionizing power of radiation.

The choice of a particular detector type for application depends upon the X-ray or gamma energy range of interest and the application resolution and efficiency requirements [7].

In this work dosimetric investigations were performed in various geographic places, mostly connected to anthropogenic activities. Equivalent dose rate was measured with a radiometer SRP - 68, 0,3 $\mathrm{m}$ above the point of investigation. The temperature of the air was $2{ }^{\circ} \mathrm{C}$.

The device SRP-68 was used for investigating land radioactivity, ores with radioactive additives and for other geological works. The device SRP-68 is a portable radiometer. It consists of a detecting block which changes gamma quants to electrical impulses and controls.

One experiment took place at points in a tunnel and above it. There were eighty-five points where measurements of equivalent dose rate were made with a dosimeter. At each point equivalent dose rate was measured three times and its average value was calculated. The distance from the points where measurements were made

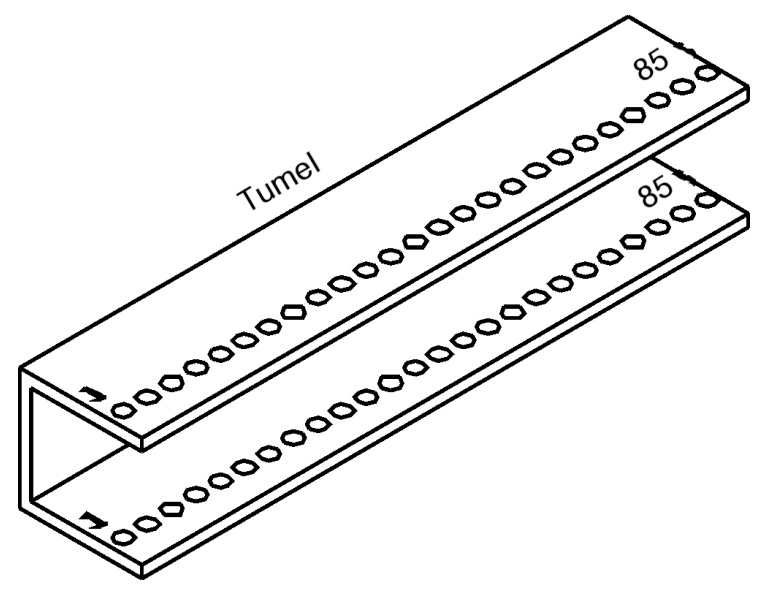

Fig 1. Scheme of measuring points in a tunnel was $0,5 \mathrm{~m}$. The points were situated in a straight line. This place was in the center of Vilnius city near the same building. The scheme of points where equivalent dose rate was measured is shown in Fig 1.

Another experiment took place at points in a garage. There was twenty-one point where measurements of equivalent dose rate were made with a dosimeter. The first, the second and the third points were outside the garage, the rest of the points were inside it. At each point equivalent dose rate was measured three times. After processing measurement data calculations of equivalent dose rate at each measuring point were made. The distance from the points where measurements of equivalent dose rate were made was $0,5 \mathrm{~m}$. This garage was in Vilnius city on Žirmūnai street. The scheme of the points where equivalent dose rate was measured is shown in Fig 2.

Another experiment took place in an arable field and non-arable one with grass. The field with grass was compared with the arable soil. There were two points where equivalent dose rate was measured in the field with grass. The third point was at the border between the field with grass and arable soil field. Other points were in the arable soil field. The distance between the points was $0,5 \mathrm{~m}$. This field is near a road. The scheme of measurements is shown in Fig 3. Thirteen points were measured for this experiment. Thirteen measurements were made at one point. An average value of equivalent dose rate was calculated. Time between each measurement at one point was about ten seconds.

Equivalent dose rate was measured at the points that were situated in a trench. The ground in which a trench was dug was mostly from sand, gravel and clay. This trench was dug for laying pipes. There were five points where measurements of equivalent dose rate were made with a dosimeter. The first point was at the bottom of the trench, the last one was at the ground level. At each point equivalent dose rate was measured four times. After processing the measurement data, calculation of equivalent dose rate at each measuring point was made. This place was in Vilnius city on Žirmūnai street. The

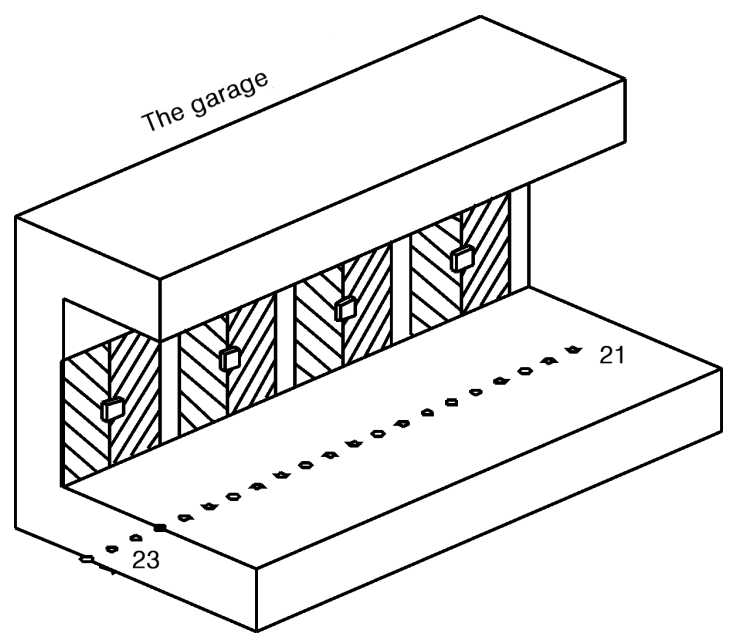

Fig 2. Scheme of measuring points in a garage 


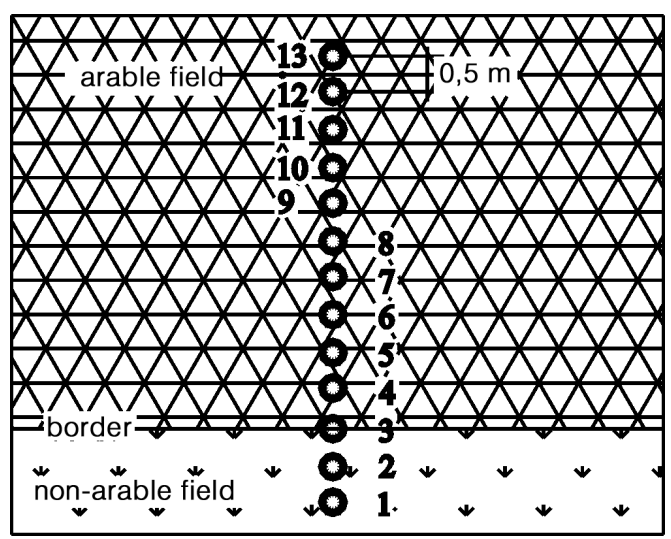

Fig 3. Scheme of measuring points in an arable and nonarable fields

distance from the points where measurements of equivalent dose rate were made was $0,5 \mathrm{~m}$.

The main gamma radioactivity sources ${ }^{40} \mathrm{~K}$ and ${ }^{226} \mathrm{Ra}$ and their concentration in the soil of equivalent dose rate measurement places were evaluated. Radionuclide concentrations for gamma-active radionuclides were determined with gamma spectrometry. This method can be used for different types of samples including soil and sediment samples, ground waters, bottled waters, effluent wastes, etc. The samples of the soil were taken from the trench every $0,5 \mathrm{~m}$ going upwards. Pipes were put in that trench. The samples of the soil were brought to the laboratory in polyethylene bags, dried, weighed, the density was determined and the specific activity was measured in a standard vessel. Gamma radiation activity was determined with a semiconductor scintillation $\mathrm{NaI}(\mathrm{Tl})$ spectrometer Canberra [7]. The samples were measured in $200 \mathrm{ml}$ bulbs.

The efficiency of a spectrometer of gamma registration $\mathrm{Ge}(\mathrm{Li})$ was $0,26 \%$, but for scintillation spectrometer Canberra - 0,79\%. Radionuclides were identified according to the following energetic lines: ${ }^{226} \mathrm{Ra}-$ $186 \mathrm{keV},{ }^{40} \mathrm{~K}-1460 \mathrm{keV}$. The measured activity of a sample was calculated for the unit of mass.

\section{Measurement results}

After the investigation was performed, all the data were statistically processed and charts were drawn. These charts show the dependence of the equivalent dose rate of natural radionuclides on the location of a point.

As a result of an experiment in a tunnel (Fig 4), a chaotic dispersion of the values of measured equivalent dose rate in the tunnel and above it is seen. The equivalent dose rate, which is measured in a tunnel, has higher values (176-219 nSv/h) in comparison with the equivalent dose rate, which is measured above a tunnel (120$147 \mathrm{nSv} / \mathrm{h}$ ). Higher equivalent dose rate values in a tunnel are due to building materials used to build this tunnel. In the chart it is shown that in the middle of a tunnel the equivalent dose rate values are higher than those at its end and beginning. This is because of a bad ventilation in the middle part of the tunnel. It is very important to continue radioactivity measurements in a tunnel in order to obtain sufficient data for statistical processing.

From measurements in a garage (Fig 5), it is seen that equivalent dose rate outside the garage $(151 \mathrm{nSv} / \mathrm{h})$ is lower than inside it (169-209 nSv/h). The splitting of radon products causes it. It was noticed that equivalent dose rate got higher going to the end of the garage. It was getting higher by the dependence $y=1,5+162$. This is because of a bad ventilation at the end of the garage.

In Fig 6 equivalent dose rate distribution in an arable part of a field and non-arable part of the same field was drawn. Points 1 and 2 are in a non-arable field with grass. Point 3 is above the border of an arable and non-

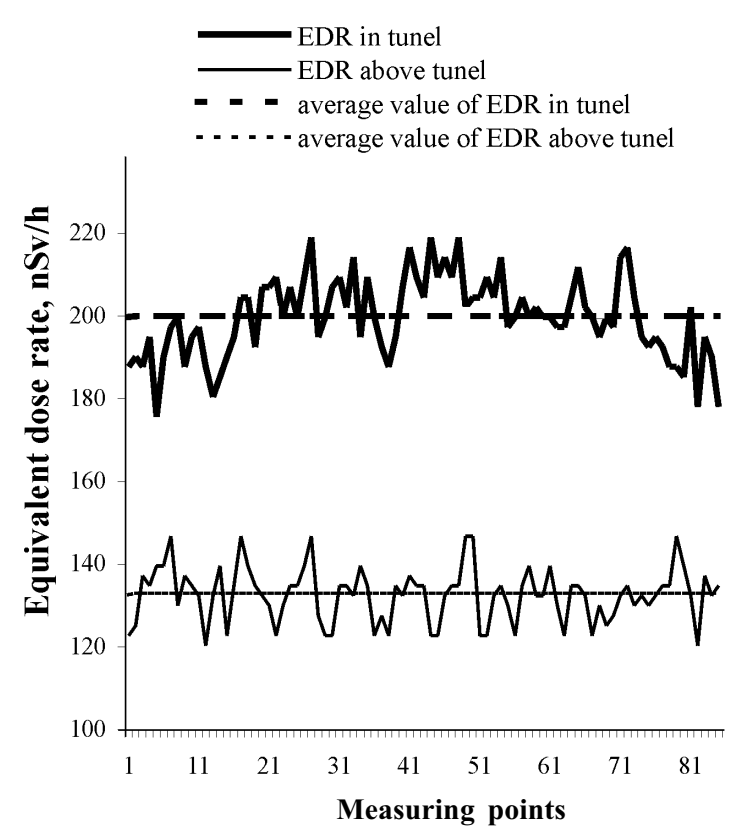

Fig 4. Distribution values of equivalent dose rate in a tunnel and above it

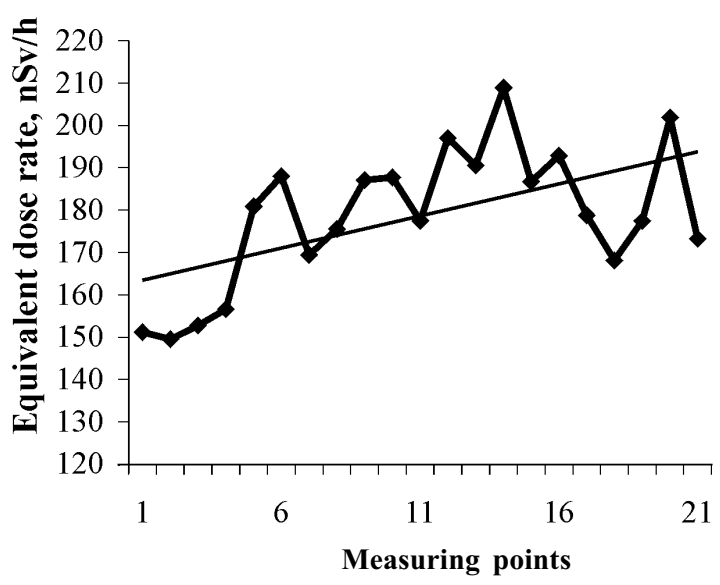

Fig 5. Distribution values of equivalent dose rate inside a garage and outside it 


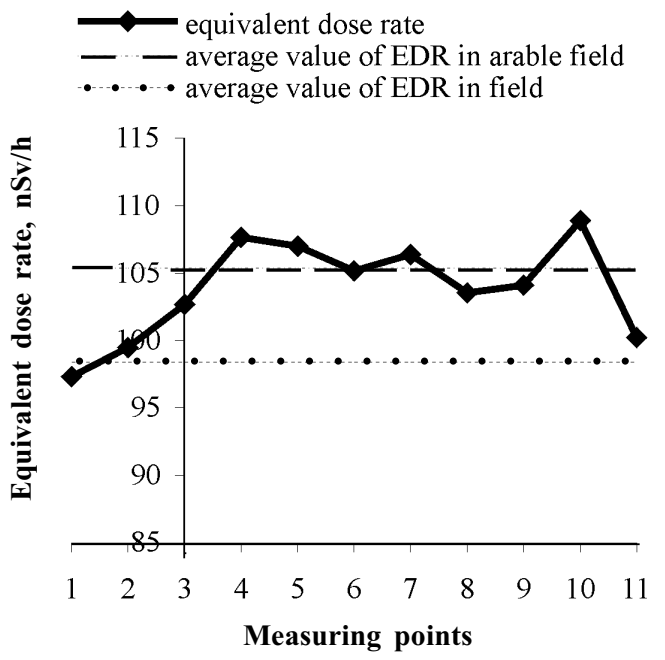

Fig 6. Distribution values of equivalent dose rate in an arable and non-arable fields

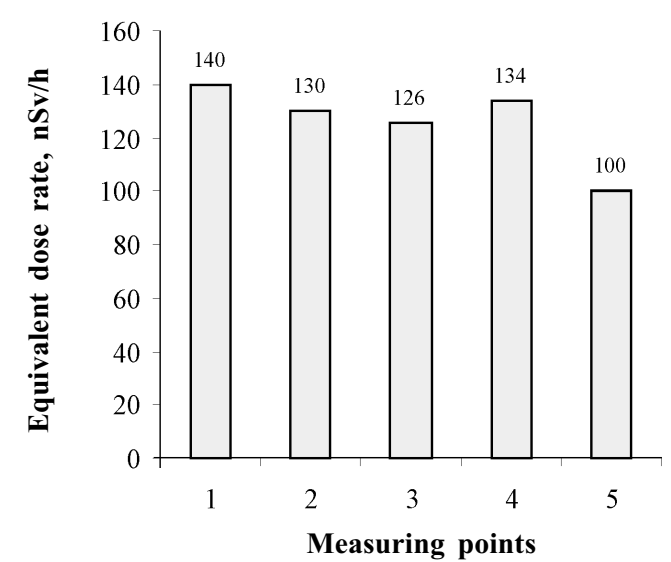

Fig 7. Distribution values of equivalent dose rate in a trench

arable fields. The rest points are situated in the arable part of a field. The lower line shows an average value of equivalent dose rate in a field with grass. The upper line shows an average value of equivalent dose rate in an arable field. As a result of this measurement, it is seen that equivalent dose rate in a field with grass has a lower value $(97 \mathrm{nSv} / \mathrm{h})$ than in an arable soil $(104 \mathrm{nSv} /$ h). The differences are very small. This can be explained in one way: it is because of radon in the ground. But it can also be that the soil constitution in different parts of this field is different. In an arable part of the field there can be the same clay impurity. For a particular analysis of this situation, a spectrometric analysis must be made.

As a result of an experiment in a trench (Fig 7), dependence on the height for values of measured equivalent dose rate in the trench is seen. It is seen that the highest value of equivalent dose rate $(140 \mathrm{nSv} / \mathrm{h})$ was at point 1 , that is at the bottom of the trench. The lowest value of equivalent dose rate $(100 \mathrm{nSv} / \mathrm{h})$ was at point 5 , that is at the ground level. This is because of the splitting of radon and its decay products in the ground. A

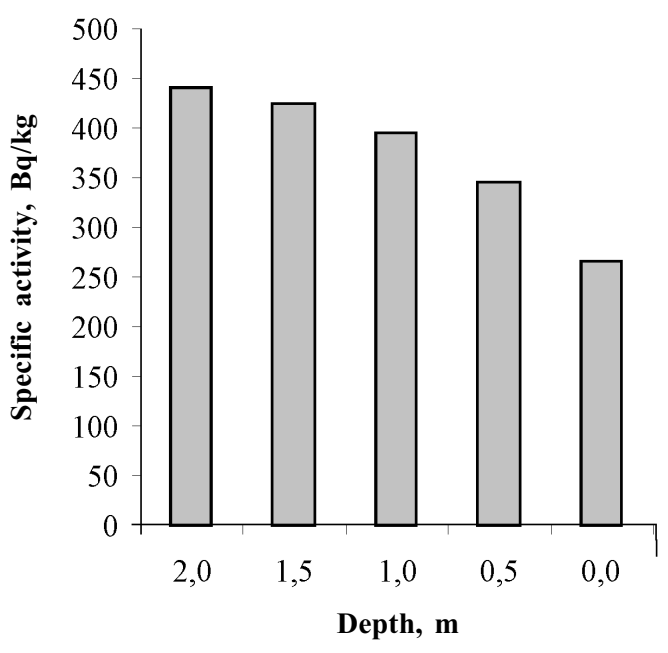

Fig $8 .{ }^{40} \mathrm{~K}$ distribution of specific activity in the soil

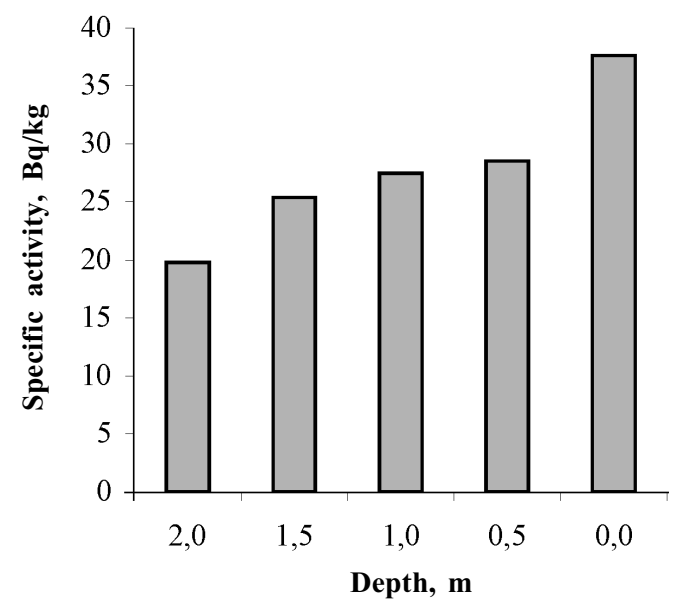

Fig 9. ${ }^{226} \mathrm{Ra}$ distribution of specific activity in the soil

spectrometric analysis will be made for this experiment in order to determine the value of specific activity.

After a spectrometric analysis of the ground that was freshly dug from a trench dependence on the height for values of the measured specific activity of ${ }^{40} \mathrm{~K}$ and ${ }^{226} \mathrm{Ra}$ is seen (Figs 8, 9). It was determined that the specific activity of ${ }^{40} \mathrm{~K}$ was higher than that of ${ }^{226} \mathrm{Ra}$. It is seen that the highest value of specific activity of ${ }^{40} \mathrm{~K}(441 \mathrm{~Bq} /$ $\mathrm{kg}$ ) was at point 1 , that is at the bottom of a trench. The lowest value of the specific activity of ${ }^{40} \mathrm{~K}(267 \mathrm{~Bq} / \mathrm{kg})$ was at point 5 , that is at the ground level. This is because of the splitting of radon in the ground. The highest value of the specific activity of ${ }^{226} \mathrm{Ra}(37 \mathrm{~Bq} / \mathrm{kg})$ was at point 5 , that is at the ground level of a trench. The lowest value of the specific activity of ${ }^{226} \mathrm{Ra}(19 \mathrm{~Bq} / \mathrm{kg})$ was at point 1 , that is at the bottom of a trench.

\section{Conclusions}

After dosimetric investigations in various geographic places it is determined that: 
1. Equivalent dose rate above an arable field $(108 \mathrm{nSv} / \mathrm{h})$ is higher than that above a non-arable field $(97 \mathrm{nSv} / \mathrm{h})$. It is because of radioactive elements in deeper layers of the soil.

2. The equivalent dose rate of ionizing radiation in a tunnel $(176-219 \mathrm{nSv} / \mathrm{h})$ is higher than that above a tunnel (120-147 $\mathrm{nSv} / \mathrm{h})$. Higher values of the equivalent dose rate of ionizing radiation in a tunnel are caused by the ionized radiation of radionuclides in the building material of a tunnel.

3. Equivalent dose rate in an underground garage $(169-209 \mathrm{nSv} / \mathrm{h})$ is higher than that outside the garage $(151 \mathrm{nSv} / \mathrm{h})$. The splitting of radon products causes it.

4. After a spectrometric analysis of the ground that was freshly dug from a trench, it is determined that the highest specific activity of ${ }^{40} \mathrm{~K}$ is at the deepest point $(441 \mathrm{~Bq} / \mathrm{kg})$, the highest value of the specific activity of ${ }^{226} \mathrm{Ra}$ is at the highest point $(37 \mathrm{~Bq} / \mathrm{kg})$.

\section{References}

1. Environmental monitoring of artificial and natural radionuclides in marine samples. http://www.ipen.br/sar/progress/ pdf/2_1_1_16.pdf, 2003.10.24, p. 2.

2. Radionuclides in well water. http://www.gov.ns.ca/enla/ water/radiofaq.pdf, 2005.10.24, p. 4.

3. Butkus, D; Lebedyte, M. et al. Radionuclides in environmental. Ecological longevity of Lithuania in the historic context. Vilnius, 1999, p 120-157 (in Lithuanian).

4. Srentz, A. K. Some characteristics of surface water and soils from the region of the Upper Flow of Arda River. Observatoire de Montaghe de Moussala, No 7. Sofia, 1997, p 38-54 (in Bulgaria).

5. Allen, E. Fundamentals of building construction materials and methods. New York: John Wiley \& Sons. Inc, 1999. $150 \mathrm{p}$.

6. Chadyšienè, R; Pečiulienè, M; Girgždys, A. Variations of ionizing radiation in urbanized territories. Journal of Environmental Engineering and Landscape Management, Vol XII. Supp 2. Vilnius: Technika, 2004, p 37-41 (in Lithuanian).

7. Gamma and X-Ray Detection. http://www.canberra.com/ literature/931.asp, 21 Mar 2004.

\section{GAMTINĖS JONIZUOJANČIOSIOS SPINDULIUOTĖS POKYČIAI ŽMOGAUS VEIKLOS OBJEKTUOSE}

\section{Bogdevičienė, M. Pečiulienė, A. Girgždys}

S a n tra u a

Atlikti dozimetriniai bei spektrometriniai tyrimai įvairiose geofizinèse vietose, labiausiai susijusiose su antropogenine veikla. Lygiavertès dozès galia išmatuota radiometru SRP-68 0,3 m aukštyje virš tiriamo taško. Nustatyta, kad lygiavertès dozès galia kinta nuo $97 \mathrm{nSv} / \mathrm{h}$ dirvoje iki $219 \mathrm{nSv} / \mathrm{h}$ tunelyje. Didžiausios gamtinès kilmès radionuklidų sukeltos lygiavertès dozès galios reikšmės yra uždarose, blogai vėdinamose patalpose. Pastebėta, kad ${ }^{40} \mathrm{~K}$ ir ${ }^{226} \mathrm{Ra}$ savitasis aktyvumas priklauso nuo gylio. ${ }^{40} \mathrm{~K}$ savitasis aktyvumas didžiausias giliausiame taške $(441 \mathrm{~Bq} / \mathrm{kg})$, o ${ }^{226} \mathrm{Ra}$ - atvirkščiai - aukščiausiame taške $(37 \mathrm{~Bq} / \mathrm{kg})$.

Raktažodžiai: jonizuojančioji spinduliuotè, gamtinès kilmès radionuklidai, dozimetrija, lygiavertès dozės galia, savitasis aktyvumas.

Viktorija BOGDEVIČIENĖ. Master student, Dept of Environmental Protection, Vilnius Gediminas Technical University (VGTU).

Milda PEČIULIENĖ. Doctoral student, Dept of Physics, Vilnius Gediminas Technical University (VGTU).

Doctoral student (physics), VGTU, since 2002. Master of Ecology, VGTU, 2000. Publications: co-author of 6 research papers. Research interests: environmental physics, natural radioactivity, anthropogenic impact.

Aloyzas GIRGŽDYS. Dr, head of Laboratory of Nuclear Hydrophysics, Vilnius Gediminas Technical University (VGTU).

Doctor of Science (environmental physics), Moscow Institute of Atmospheric Physics, 1985. First degree in Physics, Vilnius University (VU), 1970. Publications: author of 1 monograph, over 120 research papers. Research interests: environmental physics, aerosol physics. 